OPEN ACCESS

Edited by:

Richard K. F. Unsworth,

Swansea University, UK

Reviewed by:

Zhenzhu Xu,

Chinese Academy of Sciences, China Matthew Philip Adams,

The University of Queensland,

Australia

${ }^{*}$ Correspondence:

Kasper E. Brodersen elgetti@hotmail.com

Ole Pedersen

opedersen@bio.ku.dk

Specialty section: This article was submitted to Functional Plant Ecology,

a section of the journal

Frontiers in Plant Science

Received: 08 December 2016 Accepted: 10 April 2017

Published: 09 May 2017

Citation:

Brodersen KE, Hammer KJ Schrameyer $V$, Floytrup A Rasheed MA, Ralph PJ, Kühl M and

Pedersen O (2017) Sediment

Resuspension and Deposition on Seagrass Leaves Impedes Internal

Plant Aeration and Promotes

Phytotoxic $\mathrm{H}_{2} \mathrm{~S}$ Intrusion.

Front. Plant Sci. 8:657.

doi: 10.3389/fpls.2017.00657

\section{Sediment Resuspension and Deposition on Seagrass Leaves Impedes Internal Plant Aeration and Promotes Phytotoxic $\mathrm{H}_{2} \mathrm{~S}$ Intrusion}

\author{
Kasper E. Brodersen ${ }^{1 *}$, Kathrine J. Hammer ${ }^{2}$, Verena Schrameyer ${ }^{1}$, Anja Floytrup ${ }^{2}$, \\ Michael A. Rasheed ${ }^{3}$, Peter J. Ralph ${ }^{1}$, Michael Kühl ${ }^{1,4}$ and Ole Pedersen ${ }^{2,5 *}$ \\ ${ }^{1}$ Climate Change Cluster, Faculty of Science, University of Technology Sydney, Sydney, NSW, Australia, ${ }^{2}$ Freshwater \\ Biological Laboratory, Department of Biology, University of Copenhagen, Copenhagen, Denmark, ${ }^{3}$ Centre for Tropical Water \\ and Aquatic Ecosystem Research (TropWater), James Cook University, Cairns, QLD, Australia, ${ }^{4}$ Marine Biological Section, \\ Department of Biology, University of Copenhagen, Helsingør, Denmark, ${ }^{5}$ School of Plant Biology, The University of Western \\ Australia, Crawley, WA, Australia
}

\section{HIGHLIGHTS:}

- Sedimentation of fine sediment particles onto seagrass leaves severely hampers the plants' performance in both light and darkness, due to inadequate internal plant aeration and intrusion of phytotoxic $\mathrm{H}_{2} \mathrm{~S}$.

Anthropogenic activities leading to sediment re-suspension can have adverse effects on adjacent seagrass meadows, owing to reduced light availability and the settling of suspended particles onto seagrass leaves potentially impeding gas exchange with the surrounding water. We used microsensors to determine $\mathrm{O}_{2}$ fluxes and diffusive boundary layer (DBL) thickness on leaves of the seagrass Zostera muelleri with and without fine sediment particles, and combined these laboratory measurements with in situ microsensor measurements of tissue $\mathrm{O}_{2}$ and $\mathrm{H}_{2} \mathrm{~S}$ concentrations. Net photosynthesis rates in leaves with fine sediment particles were down to $\sim 20 \%$ of controls without particles, and the compensation photon irradiance increased from a span of 20-53 to 109-145 $\mu \mathrm{mol}$ photons $\mathrm{m}^{-2} \mathrm{~s}^{-1}$. An $\sim 2.5$-fold thicker DBL around leaves with fine sediment particles impeded $\mathrm{O}_{2}$ influx into the leaves during darkness. In situ leaf meristematic $\mathrm{O}_{2}$ concentrations of plants exposed to fine sediment particles were lower than in control plants and exhibited long time periods of complete meristematic anoxia during night-time. Insufficient internal aeration resulted in $\mathrm{H}_{2} \mathrm{~S}$ intrusion into the leaf meristematic tissues when exposed to sediment resuspension even at relatively high night-time water-column $\mathrm{O}_{2}$ concentrations. Fine sediment particles that settle on seagrass leaves thus negatively affect internal tissue aeration and thereby the plants' resilience against $\mathrm{H}_{2} \mathrm{~S}$ intrusion.

Keywords: diffusive boundary layer, dredging, $\mathrm{H}_{2} \mathrm{~S}$, in situ, microsensors, photosynthesis, seagrass, sediment 


\section{INTRODUCTION}

Anthropogenic activities in coastal waters such as dredging, point-source outfall discharges and runoff from agricultural and urban catchments lead to addition and resuspension of fine particulate material that can have substantial negative impacts on the health and fitness of seagrasses (Erftemeijer and Lewis, 2006 and references herein; York et al., 2015; Chartrand et al., 2016). Dredging operations e.g., during harbor expansion or construction work can result in direct removal of plant material and plant burial by suspended sediment. The indirect effects associated with turbid sediment plumes, have largely been attributed to reduced light availability impeding seagrass photosynthesis (e.g., Erftemeijer and Lewis, 2006; York et al., 2015). Dredging-induced seagrass mortality depends on the nature of the dredging operations including the duration and intensity (Erftemeijer and Lewis, 2006; York et al., 2015), but some larger dredging activities result in widespread sediment plumes that can significantly reduce light transmission through the water-column (Cutroneo et al., 2013). Sediment resuspension for prolonged time periods can strongly affect plant fitness. Even small reductions in light availability can cause pronounced declines in the distribution and growth of seagrass meadows (Ralph et al., 2007; Chartrand et al., 2016). Seagrasses generally have high light requirements and are therefore typically found in waters, where at least $10 \%$ of incident solar irradiance reaches the seagrass leaf canopy (Duarte, 1991).

Apart from light attenuation, sediment plumes can also result in the settling of fine sediment particles on seagrass leaves, especially if the plants are already covered by epiphytes that have high potential to trap the sediment e.g., due to their excretion of exopolymers (Pereira et al., 2009; Hamisi et al., 2013). The effects of such sediment coverage on the performance of seagrasses remain largely unexplored although such sediment layers may result in a further substantial reduction in light availability for the underlying leaves, analogous to the adverse shading effects of leaf epiphytes (Brodersen et al., 2015a). Epiphytic microalgae on seagrass leaves have also been shown to significantly increase the thickness of the diffusive boundary layer (DBL) (Koch, 1994; Brodersen et al., 2015a), that is a thin unstirred layer of water, wherein solute and gas exchange between tissues and the surrounding water occurs by molecular diffusion, which is a slow process compared to bulk exchange of solutes/gasses (e.g., Jørgensen and Revsbech, 1985; Hurd, 2000). The transport time of $\mathrm{O}_{2}$ across the DBL increases with the square of the DBL thickness, i.e., the diffusion path length, and increasing DBL thickness will thus affect the $\mathrm{O}_{2}$ exchange of the seagrass leaf substantially (Jørgensen and Des Marias, 1990; Hurd, 2000; Larkum et al., 2003; Binzer et al., 2005). During the day, thick DBLs may result in increased photorespiration due to tissue accumulation of $\mathrm{O}_{2}$ (e.g., Maberly, 2014), but thick DBLs can be particularly problematic during darkness, where seagrasses completely rely on the diffusive supply of $\mathrm{O}_{2}$ from the surrounding water-column to maintain aerobic respiration of their leaves and below-ground tissues (Borum et al., 2006; Pedersen et al., 2016).
Sediment resuspension may also result in decreased watercolumn $\mathrm{O}_{2}$ concentrations due to (i) chemical oxidation of reduced metabolites and metals (Erftemeijer and Lewis, 2006), or (ii) increased aerobic mineralization of labile organic matter accumulated in the sediment under anoxic conditions. The chemical and biological $\mathrm{O}_{2}$ demand of suspended particles adds to the substantial $\mathrm{O}_{2}$ consumption by dense seagrass meadows during night-time, potentially resulting in watercolumn hypoxia (Greve et al., 2003; Borum et al., 2005, 2006). Night-time water-column hypoxia can result in inadequate internal aeration of belowground seagrass tissues resulting in shrinking or disappearance of the oxic micro-shield generated by radial $\mathrm{O}_{2}$ loss (ROL) in the rhizosphere (Koren et al., 2015; Brodersen et al., 2015b). Decreased or absent ROL, can result in intrusion of gaseous phytotoxic $\mathrm{H}_{2} \mathrm{~S}$ from the surrounding anoxic sediment into the plant. Once in the plant, the strong binding capacity of $\mathrm{H}_{2} \mathrm{~S}$ with iron in cytochrome $c$ oxidase in the mitochondrial respiratory electron transport chain may inhibit the seagrass metabolism and lead to increased mortality (Raven and Scrimgeour, 1997; Holmer and Bondgaard, 2001; Pérez-Pérez et al., 2012; Lamers et al., 2013). Such $\mathrm{H}_{2} \mathrm{~S}$ intrusion into seagrasses has been demonstrated both under controlled conditions in the laboratory (Pedersen et al., 2004) and in a die-off patch in the field (Borum et al., 2005). Interestingly, seagrasses possess internal detoxification mechanisms, whereby some tissue $\mathrm{H}_{2} \mathrm{~S}$ is oxidized to elemental sulfur within the aerenchyma (Holmer and HaslerSheetal, 2014; Hasler-Sheetal and Holmer, 2015). Adequate internal plant aeration is thus a perquisite for healthy seagrass meadows.

The $\mathrm{O}_{2}$ partial pressure $\left(p \mathrm{O}_{2}\right)$ of seagrass tissues is determined by four main factors: (i) the diffusive $\mathrm{O}_{2}$ flux from the watercolumn into the leaves during darkness (Pedersen et al., 2004), (ii) photosynthetic $\mathrm{O}_{2}$ production during the day (Dennison, 1987; Fourqurean and Zieman, 1991), (iii) the respiratory demand of the plant that is strongly affected by the ambient temperature (Raun and Borum, 2013), and (iv) the combined sediment $\mathrm{O}_{2}$ demand affecting the ROL in the rhizosphere (Pedersen et al., 1998; Jensen et al., 2005; Borum et al., 2006; Frederiksen and Glud, 2006).

In the present study, we combined experimental sediment resuspension experiments with microsensor measurements to investigate (i) the rates of photosynthesis and respiration, (ii) the potential role of settled sediment particles on DBLimpedance of $\mathrm{O}_{2}$ exchange with the water-column, (iii) the internal $\mathrm{O}_{2}$ status of the meristematic tissue, and (iv) the meristematic $\mathrm{H}_{2} \mathrm{~S}$ concentrations in the seagrass Zostera muelleri spp. capricorni. Detailed microsensor measurements were performed both under controlled laboratory conditions and in situ, and were coupled to the light, temperature and $\mathrm{O}_{2}$ conditions in the surrounding water-column. We thus tested the hypotheses that sediment deposits on seagrass leaves lead to (i) reduced photosynthetic efficiency, owing to reduced light availability, as well as reduced gas exchange with the surrounding water column, (ii) reduced internal aeration of below-ground seagrass tissue, and (iii) intrusion of $\mathrm{H}_{2} \mathrm{~S}$ into the seagrass. Our data add important ecophysiological information on the 
resilience/sensitivity of seagrasses to environmental disturbances linked to anthropogenic activities associated with increases in suspended sediments.

\section{MATERIALS AND METHODS}

\section{Seagrass and Sediment Collection}

Specimens of Z. muelleri spp. capricorni (Asch.) S.W.L. Jacobs and marine sediment were collected from shallow waters $(<2 \mathrm{~m}$ depth) in Narrabeen Lagoon, NSW, Australia in April 22, 2015. Narrabeen Lagoon is a large $\left(\sim 2 \mathrm{~km}^{2}\right)$, shallow intermittently closed lagoon, with a catchment area of $\sim 55 \mathrm{~km}^{2}$. A plastic corer with an inner diameter of $6.3 \mathrm{~cm}$ was used to sample bulk sediment cores adjacent to the investigated seagrass meadow. After sampling, seagrasses and sediment were transported to the laboratory, where they were kept in constantly aerated seawater reservoirs $\left(23^{\circ} \mathrm{C}\right.$; salinity $=29$; mimicking physicochemical water-column conditions at the sampling site) prior to further investigations.

\section{Sediment Sieving}

Multiple sieves were used to obtain the fine sediment particle fraction with $<63 \mu \mathrm{m}$ grain size, henceforth referred to as silt/clay, from a sheltered area of the lagoon. After sieving, the obtained silt/clay particles and water were left undisturbed overnight in enclosed $10 \mathrm{~L}$ containers to allow the suspended particles to resettle. On the following day, the supernatant was carefully drained off avoiding resuspension, and the silt/clay fraction was stored in $1 \mathrm{~L}$ sample jars for up to 7 days until used in subsequent experiments. Furthermore, to enable differentiation between physical effects caused by the grains themselves and effects mainly driven by microbial activity within the silt/clay, some of the obtained silt/clay was sterilized by heating it to $120^{\circ} \mathrm{C}$ in an oven for $2 \mathrm{~h}$ within sealed containers to minimize evaporation.

\section{Laboratory Measurements \\ Experimental Setup}

Leaf segments from 3 randomly selected Z. muelleri plants were positioned horizontally in a custom-made flow chamber (Brodersen et al., 2014). Within the chamber, leaf segments were fixed onto a polystyrene plate by needles. The cut ends of the investigated leaf segments were sealed with petroleum jelly prior to experiments to seal the aerenchyma from the surrounding water. A constant flow $\left(\sim 1 \mathrm{~cm} \mathrm{~s}^{-1}\right)$ of aerated seawater $\left(23^{\circ} \mathrm{C}\right.$, salinity $=29$ ) was maintained in the flow chamber via a pump submerged into a seawater reservoir. The applied flow velocity of $\sim 1 \mathrm{~cm} \mathrm{~s}^{-1}$ is in the lower end of field water velocities (e.g., Gambi et al., 1990; González-Ortiz et al., 2014), but does resemble water movement especially within dense seagrass meadows in closed lagoons such as the conditions in Narrabeen Lagoon. Illumination was provided by a fiber-optic tungsten halogen lamp fitted with a collimating lens (KL-2500LCD, Schott GmbH, Germany). The downwelling photon irradiance (PAR, 400-700 nm) at the leaf surface was measured with a scalar irradiance minisensor (US-SQS/L, Walz GmbH, Germany) connected to a calibrated photon irradiance meter (LI-250A,
LI-COR, USA). The leaf segments were illuminated with an incident photon irradiance of $0,75,200$, and $500 \mu \mathrm{mol}$ photons $\mathrm{m}^{-2} \mathrm{~s}^{-1}$. Water-column hypoxia was obtained by continuously flushing the seawater in the supporting water reservoir with a mixture of atmospheric air and humidified nitrogen gas. The $\mathrm{O}_{2}$ concentration of the water reservoir was simultaneously monitored by a submerged Clark-type $\mathrm{O}_{2}$ microsensor (OX10, tip diameter of $10 \mu \mathrm{m}$, Unisense A/S, Aarhus, Denmark; Revsbech, 1989).

\section{$\mathrm{O}_{2}$ Microsensor Measurements}

We used Clark-type $\mathrm{O}_{2}$ microsensors (OX-50, tip diameter of $\sim 50 \mu \mathrm{m}$, detection limit $\sim 0.3 \mu \mathrm{M}$, Unisense A/S, Aarhus, Denmark; (Revsbech, 1989)) with a fast response time $\left(t_{90}\right.$ $<0.5 \mathrm{~s})$ and a low stirring sensitivity $(<2-3 \%)$ to measure the $\mathrm{O}_{2}$ concentration at and toward the leaf surface. The $\mathrm{O}_{2}$ microsensors were mounted on a motorized micromanipulator (Unisense A/S, Aarhus, Denmark) and connected to a microsensor multimeter (Unisense A/S, Aarhus, Denmark) both interfaced with a PC running dedicated data acquisition and positioning software (SensorTrace Pro, Unisense A/S, Aarhus, Denmark). The $\mathrm{O}_{2}$ microsensors were linearly calibrated from signal readings in $100 \%$ air saturated seawater and anoxic seawater (by $\mathrm{N}_{2}$ flushing and addition of the $\mathrm{O}_{2}$ scavenger $\mathrm{Na}_{2} \mathrm{SO}_{3}$ ) at experimental temperature and salinity. Prior to measurements and calibrations, the microsensors were preconditioned with $\mathrm{H}_{2} \mathrm{~S}$ to prevent drifting calibrations when exposed to $\mathrm{H}_{2} \mathrm{~S}$ during experiments (Brodersen et al., 2015a). Microsensors were carefully positioned at the leaf tissue surface (defined as $0 \mu \mathrm{m}$ distance on figures) by manually operating the micromanipulator, while observing the leaf tissue surface and microsensor tip with a boom-stand dissection microscope (AmScope, Irvine, CA, USA). When changing the downwelling photon irradiance, steady state $\mathrm{O}_{2}$ conditions at the leaf surface re-occurred after $\sim 60 \mathrm{~min}$ (data not shown). Microprofiles of $\mathrm{O}_{2}$ concentration were measured in vertical increments of $100 \mu \mathrm{m}$, from the leaf tissue surface to $2 \mathrm{~mm}$ distance away (which is in the same order of magnitude as the leaf tissue thickness).

\section{Photosynthesis and Respiration Calculations}

$\mathrm{O}_{2}$ fluxes across the leaf tissue surfaces were calculated using Fick's first law of diffusion:

$$
\mathrm{J}_{\mathrm{O}_{2}}=-\mathrm{D}_{0} \frac{\partial \mathrm{C}}{\partial \mathrm{Z}}
$$

where $D_{0}$ is the molecular diffusion coefficient of $\mathrm{O}_{2}$ in seawater at experimental temperature and salinity $\left(2.14 \times 10^{-5} \mathrm{~cm}^{-2} \mathrm{~s}^{-1}\right.$; cf. tabulated physical parameters for marine systems available at www.unisense.com), and $\partial C / \partial z$ is the linear $\mathrm{O}_{2}$ concentration gradient in the DBL. As we introduced a physical barrier to $\mathrm{O}_{2}$ diffusion at the abaxial surface by fixing the leaf onto polystyrene with a low $\mathrm{O}_{2}$ permeability, we take the flux estimated at the adaxial side of the seagrass leaf as representative for the net flux of $\mathrm{O}_{2}$ across the leaf surface, i.e., $J_{O 2}$, tot $=J_{O 2}$, upper-surface in dark (=respiration) and light (=net photosynthesis; assuming a photosynthetic quotient of $1 \mathrm{~mol} \mathrm{O}_{2}$ produced per mol $\mathrm{CO}_{2}$ fixed), respectively. 
The calculated net photosynthesis rates $\left(\mathrm{nmol} \mathrm{O}_{2} \mathrm{~m}^{-2} \mathrm{~s}^{-1}\right)$ as a function of the incident photon irradiance (E; $\mu \mathrm{mol}$ photons $\mathrm{m}^{-2} \mathrm{~s}^{-1}$ ) were fitted with an exponential saturation model (Webb et al., 1974) with an added term, $R$, to account for respiration (Spilling et al., 2010):

$$
\mathrm{P}_{\mathrm{n}}(\mathrm{E})=\mathrm{P}_{\max }\left(1-e^{\frac{-\alpha \mathrm{E}}{\mathrm{P}_{\max }}}\right)+\mathrm{R}
$$

This equation enables estimation of the irradiance at the onset of photosynthesis saturation as $E_{k}=P_{\max } / \alpha$, where $P_{\max }$ is the maximal net photosynthesis rate and $\alpha$ is the initial slope of the $P_{n}$ vs. $E$ curve. The compensation photon irradiance, $E_{C}$, was determined as the incident photon irradiance at which the leaf tissue shifted from a net $\mathrm{O}_{2}$ consumption to a net $\mathrm{O}_{2}$ production, i.e., the photon irradiance where $P_{n}(E)=0$.

\section{Bulk Sediment $\mathrm{O}_{2}$ Uptake}

Depth profiles of $\mathrm{O}_{2}$ concentration in the bulk sediment were obtained as follows. The sediment core was submerged into a $\sim 2$ $\mathrm{L}$ aquarium, wherein stirring and aeration of the water column was achieved via a Pasteur pipette connected to an air-pump. The surface of the sediment was determined with a boom-stand dissection microscope (AmScope, Irvine, CA, USA) and the $\mathrm{O}_{2}$ microsensors were carefully positioned at the sediment surface as described above. Microprofiles were performed in vertical increments of $200 \mu \mathrm{m}$ down to $2 \mathrm{~cm}$ depth, i.e., below the $\mathrm{O}_{2}$ penetration depth. The volume specific $\mathrm{O}_{2}$ consumption rate of the bulk sediment, $R_{\text {sed }}\left(\mu \mathrm{mol} \mathrm{O} \mathrm{m}^{-3} \mathrm{~s}^{-1}\right)$, was calculated as:

$$
\mathrm{R}_{\text {sed }}=\frac{\mathrm{J}_{\mathrm{O}_{2}}}{\mathrm{~d}_{\mathrm{O}_{2}}}
$$

where $\mathrm{J}_{\mathrm{O} 2}$ is the $\mathrm{O}_{2}$ flux at the seawater/sediment interface ( $\mu \mathrm{mol}$ $\mathrm{O}_{2} \mathrm{~m}^{-2} \mathrm{~s}^{-1}$ ), i.e., the diffusive oxygen uptake (DOU) of the sediment as calculated from Equation (1), and $d_{\mathrm{O} 2}$ is the $\mathrm{O}_{2}$ penetration depth in the sediment $(\mathrm{cm})$ as shown in Figure S1 (Supplementary Materials).

\section{Potential and Biological $\mathrm{O}_{2}$ Consumption of Sieved Sediment}

The $\mathrm{O}_{2}$ consumption of the fine sediment particles used in the laboratory as well as in situ was determined using a slightly modified approach of Pedersen et al. (2011). The $\mathrm{O}_{2}$ consumption was separated into total $\left(\mathrm{OX}_{\text {tot }}\right)$ or biological $\left(\mathrm{OX}_{\mathrm{bio}}\right) \mathrm{O}_{2}$ demand in order to determine the chemical $\mathrm{O}_{2}$ demand as $\mathrm{OX}_{\text {chem }}=\mathrm{OX}_{\text {tot }}-\mathrm{OX}_{\mathrm{bio}}$.

The total $\mathrm{O}_{2}$ consumption of the sediment fraction was determined by mixing $50 \mathrm{~mL}$ suspended sediment $(<63 \mu \mathrm{m})$ with $950 \mathrm{~mL}$ seawater with a salinity of 28. The solution was immediately transferred into $25 \mathrm{~mL}$ glass vials fitted with 2 glass beads to provide mixing and mounted on a rotating wheel $(8 \mathrm{rpm})$ in a constant temperature bath $(20.0$ $\pm 0.5^{\circ} \mathrm{C}$ ) (Pedersen et al., 2013). The sediment suspension was incubated for about $1 \mathrm{~h}$ (exact times recorded) before the $\mathrm{O}_{2}$ concentration was measured in each vial using a calibrated sturdy $\mathrm{O}_{2}$ microsensor (OX500; Unisense A/S, Denmark). Vials with seawater but without suspended sediment served as blanks enabling calculation of the $\mathrm{O}_{2}$ consumption as $\mu \mathrm{mol} \mathrm{O}_{2} \mathrm{~m}^{-3}$ sediment $\mathrm{s}^{-1}$.

The biological $\mathrm{O}_{2}$ consumption was measured on a sediment suspension, which was initially purged with atmospheric air for 15 min to oxidize reduced metals and sulfide (Raun et al., 2010). After oxidation, the sediment suspension was transferred into 25 $\mathrm{mL}$ glass vials and treated as described above.

\section{In situ Measurements \\ Experimental Setup}

Two patches $(\sim 1 \mathrm{~m}$ in diameter $)$ of $Z$. muelleri were enclosed by custom-made transparent, floating curtains with mixing provided by submerged pumps to simulate water motion outside the enclosures (Narrabeen Lagoon, Australia). One enclosure functioned as a control treatment and the other enclosure as a silt/clay treatment. In the silt/clay treatment, 3 pulses of $375 \mathrm{~mL}$ silt/clay particles (see above) were added to the water column per day to mimic a dredging operation. Sediment resuspension was initiated at the beginning of the experiments (afternoon) (pulse 1), just before sunrise (pulse 2) and at midday (pulse 3). Measurements were performed on April 17, 2015 (Series 1) and repeated on April 19, 2015 (Series 2), i.e., there were $27 \mathrm{~h}$ difference between Series 1 and Series 2 measurements. Within the enclosures, we measured salinity, light, temperature and $\mathrm{O}_{2}$ in the water column during measurements of meristematic tissue $\mathrm{O}_{2}$ and $\mathrm{H}_{2} \mathrm{~S}$ concentrations. A detailed description of the in situ measurements is given below.

\section{Internal $\mathrm{pO}_{2}$ and $\left[\mathrm{H}_{2} \mathrm{~S}\right]$ Measurements}

Similar data acquisition equipment and microsensor as described above were used for the field measurements of internal $\mathrm{O}_{2}$ partial pressure $\left(p \mathrm{O}_{2}\right)$ and $\mathrm{H}_{2} \mathrm{~S}$ concentrations $\left(\left[\mathrm{H}_{2} \mathrm{~S}\right]\right)$ in the meristematic tissue of $Z$. muelleri over diel cycles. Internal $\mathrm{H}_{2} \mathrm{~S}$ concentrations were measured with Clark-type $\mathrm{H}_{2} \mathrm{~S}$ microsensors (H2S-25, tip diameter of $\sim 25 \mu \mathrm{m}, 90 \%$ response time $<10 \mathrm{~s}$, detection limit $\sim 0.3 \mu \mathrm{m}$, Unisense $\mathrm{A} / \mathrm{S}$, Aarhus, Denmark; Jeroschewski et al., 1996; Kühl et al., 1998) that were linearly calibrated in anoxic, acidic $(\mathrm{pH} 4) \mathrm{Na}_{2} \mathrm{~S}$ solutions of known $\mathrm{H}_{2} \mathrm{~S}$ concentrations (0, 50, and $\left.100 \mu \mathrm{M}\right)$. Within the enclosures, the microsensors were mounted on micromanipulators that were supported by stabilized aluminum spears at a water depth of $\sim 1 \mathrm{~m}$. The $\mathrm{O}_{2}$ and $\mathrm{H}_{2} \mathrm{~S}$ microsensors were simultaneously inserted into the briefly-exposed shoot base of the target plants close to the basal leaf meristem, which was then re-buried $\sim 2 \mathrm{~cm}$ into the sediment to re-establish the biogeochemical gradients (Pedersen et al., 2004). Positioning of the $\mathrm{O}_{2}$ microsensors was done by observing the sensor signals during insertion until a constant signal was recorded (Borum et al., 2005). The $\mathrm{H}_{2} \mathrm{~S}$ microsensors were inserted via a similar approach, using a combination of sensor signal responses to light exposure and positioning the electrodes at approximately the same depth into the leaf meristem tissue as the $\mathrm{O}_{2}$ microsensors. The intra-plant $\mathrm{O}_{2}$ and $\mathrm{H}_{2} \mathrm{~S}$ concentrations were measured simultaneously inside one plant in the control treatment and one plant in the silt/clay treatment, and then replicated. 


\section{Physical and Chemical Parameters of the Water-Column}

Diel changes in ambient incident photon irradiance (continuously measured via Odyssey light loggers; Dataflow Systems, Christchurch, NZ), water-column $\mathrm{pO}_{2}$ (via $\mathrm{O}_{2}$ microoptodes; OXF500PT, Pyroscience, Aachen, Germany; connected to a 4-channel Firesting meter, PyroScience, Germany), and water-column temperature (via $\mathrm{HOBO}$ temperature data loggers; UA-002-08, Onset Computer Corporation, Bourne, MA, USA) were recorded over $\sim 24 \mathrm{~h}$ within the enclosures. All sensors were calibrated according to the manufactures instructions, mounted on a metal spear and positioned at leaf canopy height. Logging $(1 \mathrm{~Hz})$ by all data loggers was synchronized with the logging of microsensors used for the intra-tissue measurements.

\section{In situ calculations}

All microsensors are temperature sensitive (e.g., Kühl and Revsbech, 2001) and thus the measurements of internal $p \mathrm{O}_{2}$ and $\left[\mathrm{H}_{2} \mathrm{~S}\right]$ obtained by the calibrated $\mathrm{O}_{2}$ and $\mathrm{H}_{2} \mathrm{~S}$ microsensors were temperature corrected using the following equations (available at www.unisense.com):

$$
p \mathrm{O}_{2}=\frac{\mathrm{S}_{\mathrm{amb}}-\mathrm{Z}}{\mathrm{S}_{\mathrm{air}}-\mathrm{Z}} \mathrm{P}_{0} e^{\mathrm{k}\left(\mathrm{T}_{\mathrm{cal}}-\mathrm{T}_{\mathrm{amb}}\right)}
$$

where $S_{a m b}$ is the sensor signal measured in situ $(\mathrm{mV}), S_{\text {air }}$ is the calibration signal of the sensor determined at known partial pressure and temperature (e.g., $100 \%$ air saturation; in $\mathrm{mV}$ ), $Z$ is the zero current of the sensor measured at known partial pressure and temperature (i.e., $0 \%$ air saturation; in $\mathrm{mV}$ ), $P_{0}$ is the known partial pressure used to define $S_{\text {air }}(\mathrm{kPa}), k$ is the temperature coefficient of the respective sensor $\left(\sim 0.02^{\circ} \mathrm{C}^{-1}\right.$; exact values for individual sensors can be provided by the manufacturer, www.unisense.com), $T_{c a l}$ is the known calibration temperature $\left({ }^{\circ} \mathrm{C}\right)$, and $T_{a m b}$ is the ambient temperature $\left({ }^{\circ} \mathrm{C}\right)$ continuously measured in situ.

$$
\left[\mathrm{H}_{2} \mathrm{~S}\right]=\left(\mathrm{GS}+\mathrm{S}_{0}\right) e^{\mathrm{k}\left(\mathrm{T}_{\mathrm{cal}}-\mathrm{T}_{\mathrm{amb}}\right)}
$$

where $G$ is the slope of the calibration curve that represents the sensitivity of the sensor $\left(\mu \mathrm{mol} \mathrm{L} \mathrm{L}^{-1} \mathrm{mV}^{-1}\right), S$ is the signal of the sensor $(\mathrm{mV}), S_{0}$ is a constant that describes the zero current $\left(\mu \mathrm{mol} \mathrm{L}{ }^{-1}\right), k$ is the temperature coefficient of the respective sensor $\left(\sim 0.02^{\circ} \mathrm{C}^{-1}\right), T_{\text {cal }}$ is the known calibration temperature $\left({ }^{\circ} \mathrm{C}\right)$, and $T_{a m b}$ is the ambient temperature $\left({ }^{\circ} \mathrm{C}\right)$ continuously determined in situ.

These final sensor calibrations were done after the in situ experiments using the temperature data obtained in the respective enclosures by the submerged $\mathrm{HOBO}$ temperature data loggers (HOBO, Onset Computer Corporation, Bourne, MA, USA).

\section{Data Analysis}

In the following, $\mathrm{O}_{2}$ is quantified as $\mu \mathrm{mol} \mathrm{L}^{-1}$ when in solution and as $\mathrm{kPa}$ when in gas phase. Data obtained under controlled conditions in the laboratory, i.e., $\mathrm{O}_{2}$ fluxes across the leaf tissue surface, are thus presented in molar concentrations and data obtained in situ, i.e., meristematic $\mathrm{O}_{2}$ concentrations and water-column $\mathrm{O}_{2}$ conditions are given as partial pressures. Furthermore, all laboratory measurements were performed at 40 and $100 \%$ air equilibrium, representing water-column $\mathrm{O}_{2}$ conditions at night- and day-time, respectively. Non-linear curve fitting was used to estimate the relationship among variables. All data fitting and analyses were performed in OriginPro (OriginPro 8, OriginLab Corporation, Northampton, MA, USA).

\section{RESULTS}

\section{Laboratory Measurements}

\section{Sediment and Silt $\mathrm{O}_{2}$ Consumption Rates}

To enable comparison of sediment activity, we determined the $\mathrm{O}_{2}$ demand and characteristics of the added silt/clay particles $(<63 \mu \mathrm{m})$ and the bulk sediment without seagrass biomass. The $\mathrm{O}_{2}$ was depleted within the upper $1.2 \mathrm{~mm}$ of the bulk sediment and the sediment remained anoxic with depth (Figure S1). The volume-specific $\mathrm{O}_{2}$ consumption rate of the bulk sediment was estimated to $374 \pm 33 \mu \mathrm{mol} \mathrm{O} \mathrm{m}^{-3} \mathrm{~s}^{-1}$ (Table 1). In contrast, the fine sediment particles consumed $1319 \pm 6 \mu \mathrm{mol} \mathrm{O} \mathrm{O}^{-3}$ $\mathrm{s}^{-1}$ when taking both the biological and chemical $\mathrm{O}_{2}$ demand into account. The biological $\mathrm{O}_{2}$ demand of the silt/clay particles was $1254 \pm 29 \mu \mathrm{mol} \mathrm{O} \mathrm{m}^{-3} \mathrm{~s}^{-1}$ resulting in a chemical $\mathrm{O}_{2}$ demand of $65 \mu \mathrm{mol} \mathrm{O} \mathrm{m}^{-3} \mathrm{~s}^{-1}$ (Table 1). Hence, the chemical $\mathrm{O}_{2}$ demand of the fine sediment particles can thus most likely be neglected.

\section{Net Photosynthesis and Respiration Rates}

Net photosynthesis rates increased with increasing incident photon irradiance for both plants with and without leaf silt/claycover (Figure 1; showing $\mathrm{O}_{2}$ fluxes from/into leaves). Moreover, net photosynthesis rates were higher in control leaf segments (no silt/clay added) exposed to hypoxic water conditions, resembling water-column $\mathrm{O}_{2}$ levels at sunrise, as compared to leaf segments kept in water at $100 \%$ air equilibrium (Table 2). Plants with leaf silt/clay-cover exhibited net $\mathrm{O}_{2}$ consumption already at an incident photon irradiance of $\sim 75 \mu \mathrm{mol}$ photons $\mathrm{m}^{-2} \mathrm{~s}^{-1}$ owing to reduced light availability for leaf photosynthesis (Figure 1; Table 2). Net photosynthesis rates of the control plants were 3 to 5-fold higher under moderate photon irradiance $(200 \mu \mathrm{mol}$ photons $\mathrm{m}^{-2} \mathrm{~s}^{-1}$ ) as compared to plants with leaf silt/clay-cover

TABLE 1 | Volume specific $\mathrm{O}_{2}$ consumption rates of fine sediment

\begin{tabular}{|c|c|}
\hline Sediment type & 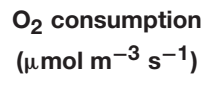 \\
\hline Bulk, sediment $\left(\mathrm{R}_{\text {sed }}\right)$ & $374 \pm 33$ \\
\hline Fine sediment particles (Biological $\mathrm{O}_{2}$ demand, $\mathrm{OX}_{\text {bio }}$ ) & $1254 \pm 29$ \\
\hline $\begin{array}{l}\text { Fine sediment particles (Biological and chemical } \mathrm{O}_{2} \\
\text { demand, } \mathrm{OX}_{\text {tot }} \text { ) }\end{array}$ & $1319 \pm 6$ \\
\hline
\end{tabular}
particles (i.e., silt/clay) and bulk sediment.

Rates are mean values $\pm S E ; n=4$. Biological $\mathrm{O}_{2}$ demand refers to the $\mathrm{O}_{2}$ consumption of fine sediment particles oxygenated via 15 min air flushing prior to measurements. Biological and chemical $\mathrm{O}_{2}$ demand of fine sediment particles refers to the $\mathrm{O}_{2}$ consumption rate of untreated, i.e., not purged with air prior to incubation, fine sediment particles. $50 \mathrm{~mL}$ fine sediment particles were added to $950 \mathrm{~mL}$ seawater. 


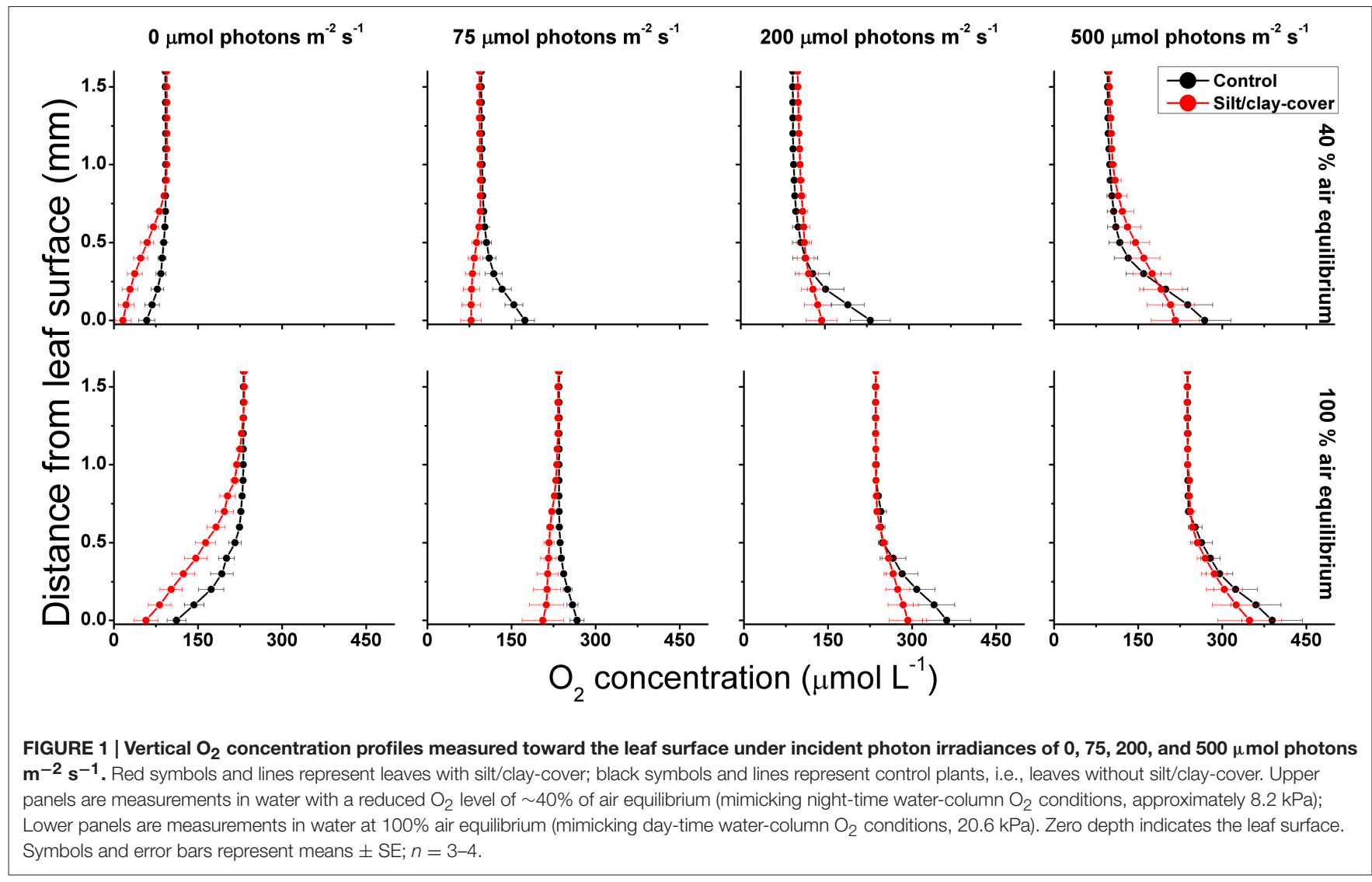

TABLE 2 | Gas exchange measured as the $\mathrm{O}_{2}$ flux across leaf surfaces of plants without (control)- and with fine sediment particles (<63 $\mu \mathrm{m}$ ) as a function of photon irradiance.

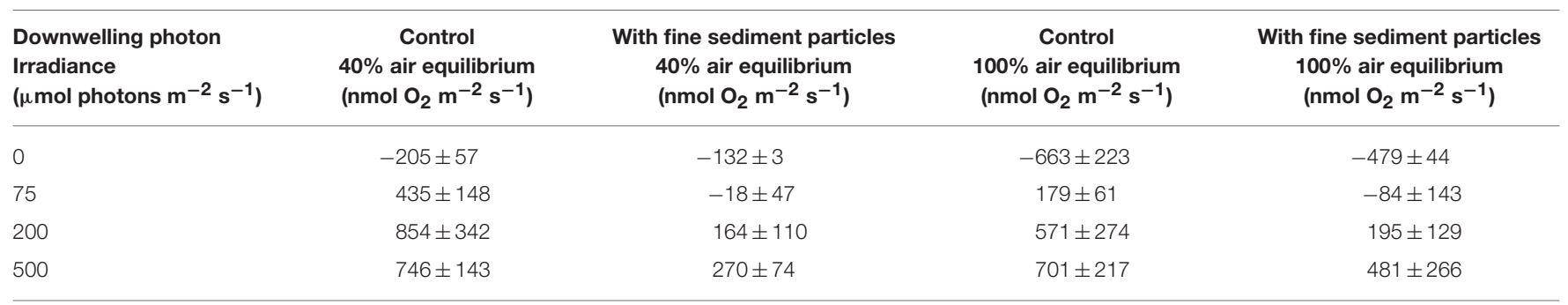

Positive values denote $\mathrm{O}_{2}$ efflux across the seagrass leaf surface. Rates are mean $\pm S E ; n=3-4$. Note that the relative high standard errors in the silt treatment at $75 \mu$ mol photons $\mathrm{m}^{-2} \mathrm{~s}^{-1}$ was due to one of the leaf segments producing $\mathrm{O}_{2}$ via photosynthesis (for further information, please see Figure S2).

(Table 2). During darkness, a constant diffusive $\mathrm{O}_{2}$ influx across the leaf surfaces of both plants with and without leaf silt/claycover was observed (Figure 1). However, we found a reduction in the $\mathrm{O}_{2}$ flux into the silt/clay-covered leaves of $28-35 \%$ as compared to leaves without silt/clay-cover (Table 2; measured at $100 \%$ and $40 \%$ air equilibrium, respectively).

During water-column hypoxia, the leaf silt/clay-layer impeded the diffusive $\mathrm{O}_{2}$ supply resulting in almost anoxic conditions at the leaf tissue surface $\left(\sim 16 \mu \mathrm{mol} \mathrm{O} \mathrm{O}_{2}^{-1}\right)$ of plants with leaf silt/clay-cover. This substantially increased the risk of $\mathrm{H}_{2} \mathrm{~S}$ intrusion into the below-ground tissues during night-time as a result of inadequate internal aeration (Figure 1). The thickness of the DBL surrounding the leaves increased from $\sim 200 \mu \mathrm{m}$ to $\sim 500 \mu \mathrm{m}$ in the presence of the leaf silt/clay layer (Figure 2). This resulted in a reduction in the $\mathrm{O}_{2}$ influx to the leaves from $484 \pm 133 \mathrm{nmol} \mathrm{O}_{2} \mathrm{~m}^{-2} \mathrm{~s}^{-1}$ in plants without leaf silt/clay-cover to $419 \pm 145 \mathrm{nmol} \mathrm{O}_{2} \mathrm{~m}^{-2} \mathrm{~s}^{-1}$ in plants with an inactivated leaf silt/clay-layer. When coated with a biologically active silt/clay layer, leaves exhibited a further reduction of the $\mathrm{O}_{2}$ influx to 395 $\pm 102 \mathrm{nmol} \mathrm{O}_{2} \mathrm{~m}^{-2} \mathrm{~s}^{-1}$ (Figure 2).

The silt/clay-cover on seagrass leaves resulted in a pronounced increase of the plants' compensation irradiance from $53 \pm 7$ $\mu \mathrm{mol}$ photons $\mathrm{m}^{-2} \mathrm{~s}^{-1}$ for control leaf segments to $145 \pm 46$ $\mu \mathrm{mol}$ photons $\mathrm{m}^{-2} \mathrm{~s}^{-1}$ for leaf segments with silt/clay cover, both kept in a water column at $100 \%$ air equilibrium (Figure 3; Table 3). In a water column with $\mathrm{O}_{2}$ kept at $40 \%$ atmospheric 


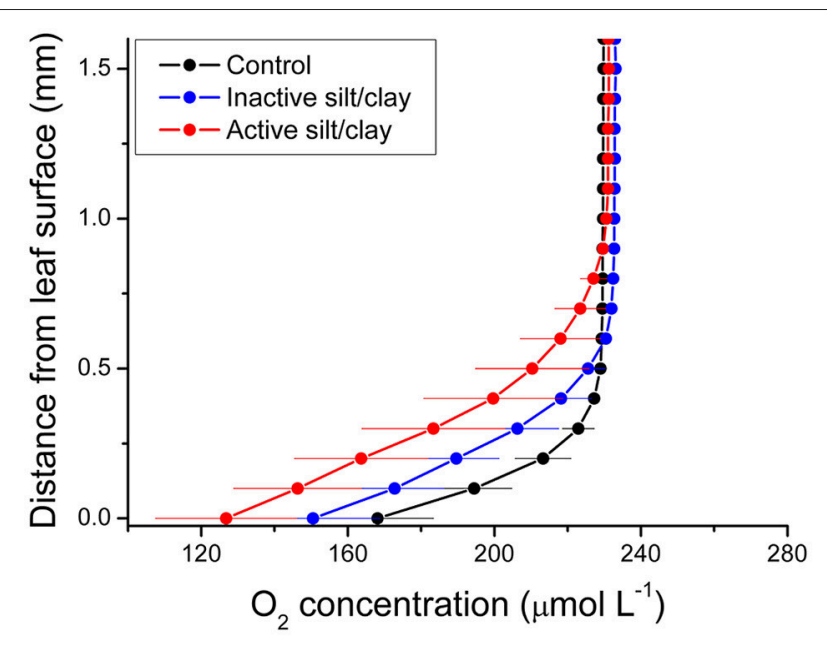

FIGURE 2 | Vertical depth profiles of the $\mathrm{O}_{2}$ concentration measured toward the leaf surface of plants with a microbially active silt/clay-cover (red symbols and lines), with an inactivated silt/clay-cover (obtained by pre-heating the added silt/clay to $120^{\circ} \mathrm{C}$ in an oven for $\mathbf{2}$ h; blue symbols and lines), and without silt/clay-cover (control plants; black symbols and lines). All measurements were performed in darkness. Zero depth indicates the leaf surface. The effective $\mathrm{DBL}$ thickness can be estimated by extrapolating the linear $\mathrm{O}_{2}$ concentration gradient until it intersects with the constant $\mathrm{O}_{2}$ concentration in the overlying water. The distance from this point into the leaf tissue surface is a measure of the effective DBL thickness (Jørgensen and Revsbech, 1985). Symbols and error bars represent means $\pm \mathrm{SE} ; n=4$ equilibrium, the compensation irradiance increased from $20 \pm$ $8 \mu \mathrm{mol}$ photons $\mathrm{m}^{-2} \mathrm{~s}^{-1}$ for control leaf segments to 109 $\pm 47 \mu \mathrm{mol}$ photons $\mathrm{m}^{-2} \mathrm{~s}^{-1}$ for leaf segments with silt/clay cover (Figure 3; Table 3). The leaf silt/clay-layer effects on plant photosynthesis and respiration lead to a $\sim 2$.4-fold increase in the irradiance causing onset of net photosynthesis saturation for plants with leaf silt/clay-cover as compared to plants without leaf silt/clay-cover (Table 3 ), and to a $49-72 \%$ reduction of the leaf surface $\mathrm{O}_{2}$ concentration in darkness for plants with a leaf silt/clay-cover as compared to plants without a leaf silt/clay-cover (Table 3).

\section{In situ Measurements and Effects of Sediment Re-suspension}

\section{Diel Changes in the Physical/Chemical Parameters of the Surrounding Water-Column}

The $\mathrm{pO}_{2}$ dynamics in the water-column of the control and silt/clay treatment showed similar patterns on a diel basis, with steadily declining $\mathrm{pO}_{2}$ during night-time reaching minimal water-column $\mathrm{O}_{2}$ conditions around sunrise, followed by a rapid increase in the water-column $\mathrm{pO}_{2}$ shortly after sunrise approaching atmospheric saturation $(20.6 \mathrm{kPa})$ or even leading to water-column supersaturation relative to atmospheric $\mathrm{pO}_{2}$ around midday (Figures 4A,B). Water-column $\mathrm{O}_{2}$ levels within the enclosures fluctuated substantially during night-time owing to water bodies with varying $\mathrm{O}_{2}$ content being introduced to the seagrass meadow from non-vegetated areas within the lagoon

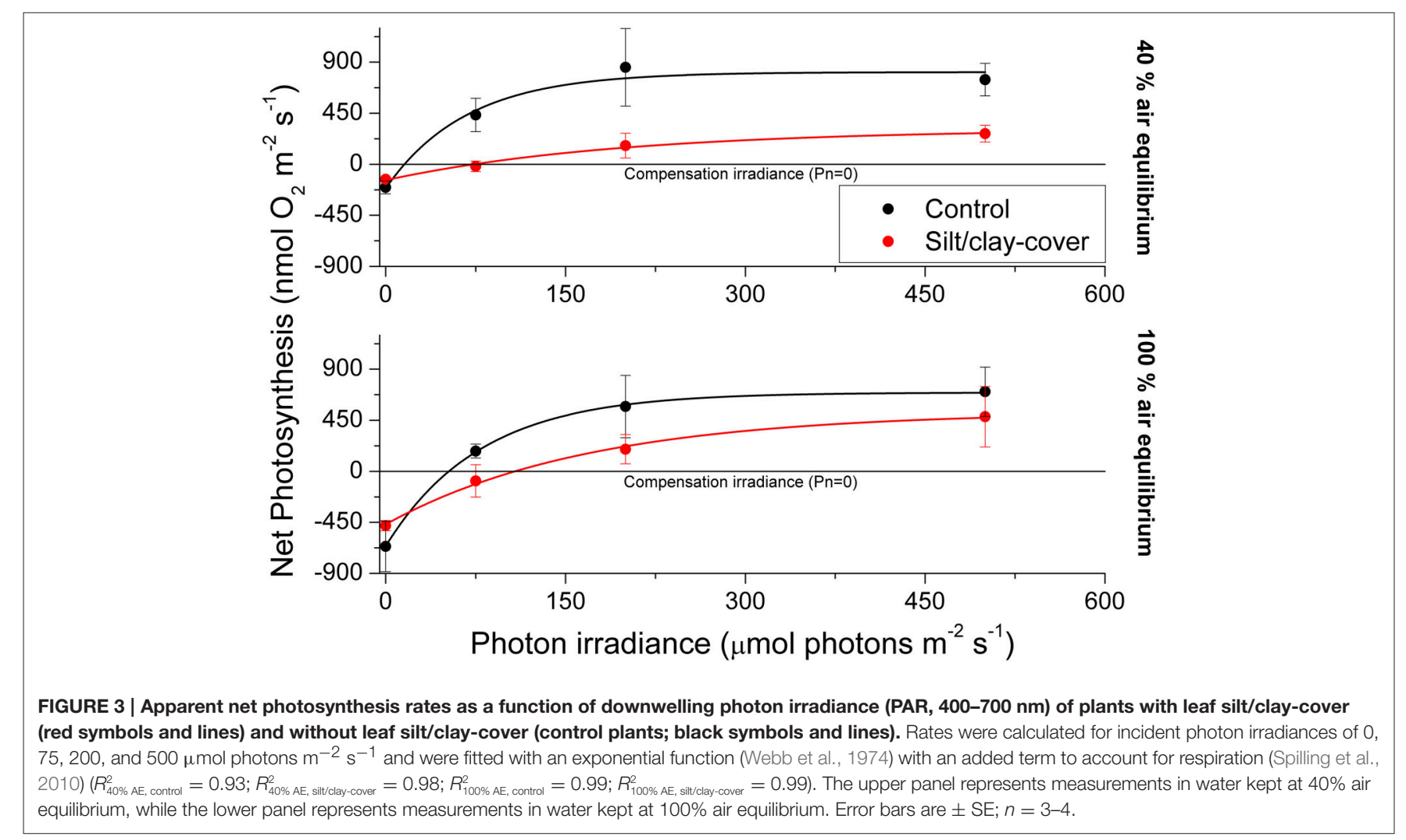


TABLE 3 | Photosynthetic parameters derived from the light response curves in Figure 3.

\begin{tabular}{lccccc}
\hline & \multicolumn{2}{c}{$\mathbf{4 0 \%}$ of air equilibrium } & & \multicolumn{2}{c}{ In air equilibrium } \\
\cline { 2 - 3 } \cline { 5 - 6 } & Control & $\begin{array}{c}\text { Fine sediment } \\
\text { particles }\end{array}$ & & Control & $\begin{array}{c}\text { Fine sediment } \\
\text { particles }\end{array}$ \\
\hline$\alpha$ & $15 \pm 4$ & $3 \pm 1$ & & $17 \pm 6$ & $6 \pm 2$ \\
$P_{\max }$ & $1028 \pm 176$ & $503 \pm 91$ & & $1354 \pm 478$ & $1010 \pm 273$ \\
$R$ & $-211 \pm 48$ & $-141 \pm 4$ & & $-662 \pm 232$ & $-468 \pm 28$ \\
$E_{C}$ & $20 \pm 8$ & $109 \pm 47$ & & $53 \pm 7$ & $145 \pm 46$ \\
$E_{k}$ & $72 \pm 5$ & $174 \pm 46$ & & $77 \pm 2$ & $180 \pm 36$ \\
$\left.O_{2}\right]$, dark & $59 \pm 14$ & $16 \pm 14$ & & $112 \pm 17$ & $57 \pm 21$ \\
\hline
\end{tabular}

Including photosynthetic activity, compensation irradiance, onset of photosynthesis saturation and respiration rates of investigated Zostera muelleri spp. capricorni plants with- and without (i.e., control plants) fine sediment particles on leaves. All photosynthetic related parameters were determined at both $40 \%$ of air equilibrium and in air equilibrium. $n=3$. Values are mean $\pm S E . \alpha=$ initial slope of the net photosynthesis rate vs. incident photon irradiance; $P_{\max }=$ maximum rate of net photosynthesis (in $\mathrm{nmol} \mathrm{O}_{2} \mathrm{~m}^{-2} \mathrm{~s}^{-1}$ ); $R$ = the respiration rate (in $\mathrm{nmol} \mathrm{O}_{2} \mathrm{~m}^{-2} \mathrm{~s}^{-1}$ ); $E_{\mathrm{C}}=$ compensation irradiance (i.e., incident photon irradiance where the oxygen produced by photosynthesis meets the respiratory demands) (in $\mu \mathrm{mol}$ photons $\mathrm{m}^{-2} \mathrm{~s}^{-1}$ ); $E_{k}=$ onset of photosynthesis saturation (in $\mu \mathrm{mol}$ photons $\left.\mathrm{m}^{-2} \mathrm{~s}^{-1}\right) ;\left[\mathrm{O}_{2}\right]$, dark = the leaf surface $\mathrm{O}_{2}$ concentration measured in darkness (in $\mu \mathrm{mol} \mathrm{L}^{-1}$ ), which can be used as an estimate for the internal $\mathrm{O}_{2}$ concentration in the aerenchymal tissue of the thin seagrass leaves. $40 \%$ of air equilibrium mimics natural conditions in the seagrass meadow during night-time and at sunrise as seen on Figure 4. Air equilibrium mimics natural conditions during most of the day-time (Figure 4). Values are calculated/extracted from the fitted exponential saturation function (Webb et al., 1974) with an added term to account for respiration (Spilling et al., 2010) in Figure 3 (apply to: $\alpha, P_{\max }, R, E_{C}$, and $\left.E_{k}\right)$ and from the $\mathrm{O}_{2}$ concentration microprofiles in Figure $1\left(\left[\mathrm{O}_{2}\right]\right.$, dark); and thus all originates from the laboratory experiments.

and/or from the ocean due to tidal water movement. In contrast, water-column temperature remained relatively constant on a diel basis but generally decreased from $\sim 22^{\circ} \mathrm{C}$ on the first measuring day (Series 1) to $\sim 20^{\circ} \mathrm{C}$ at the end of the second measuring day (Series 2). Minor fluctuations in the water-column temperature during night-time correlated with the passing of aerated water bodies as observed in the water-column $\mathrm{pO}_{2}$ measurements (Figures 4A,B). The incident photon irradiance measured at leaf canopy height followed a typical bell-shaped diel curve, with minor fluctuations in the control treatment due to passing cloud cover. This was in strong contrast to the silt/clay treatment, where we measured substantially reduced light conditions as compared to the control treatment, especially in the hours following experimentally manipulated silt/clay resuspension (Figures 4A,B). Moreover, a pronounced difference in the light availability was observed between measuring days Series 1 and Series 2, where Series 1 represented sunny conditions and Series 2 represented a cloudy late autumn day at Narrabeen Lagoon (Figures 4A,B).

\section{In situ Measurements of $\mathrm{O}_{2}$ and $\mathrm{H}_{2} \mathrm{~S}$ in Seagrass Meristems}

The internal, meristematic $\mathrm{pO}_{2}$ of both control plants and plants experimentally exposed to suspended silt/clay decreased steadily from early in the afternoon throughout the night. A minimum internal, meristematic $\mathrm{pO}_{2}$ was reached shortly after sunrise. Thereafter, a rapid increase in meristematic $\mathrm{pO}_{2}$ occurred as a response to increasing solar irradiance resulting in photosynthetic $\mathrm{O}_{2}$ production (Figures 4C,D). Control plants as well as silt/clay-treated plants exhibited lower $\mathrm{pO}_{2}$ relative to the water-column during night-time with tissue $\mathrm{pO}_{2}$ fluctuations correlating with changes in water-column $\mathrm{pO}_{2}$ (Figures 4A-D). A clear discrepancy in the meristematic $\mathrm{pO}_{2}$ between control plants and leaf silt/clay-treated plants was measured during lightlimitation in the early morning hours (06:30-09:00) (Figure 4C) with relatively lower $\mathrm{pO}_{2}$ in silt/clay-treated plants indicating a silt/clay-induced reduction in light availability.

The meristematic below-ground tissues of both control and silt/clay-treated plants turned anoxic, or severely hypoxic, late at night. Meristematic $\mathrm{pO}_{2}$ of silt/clay-treated plants reached anoxia from around 05:00-06:30 in Series 1 and already from 23:30 in Series 2, while the control plants only were exposed to anoxic conditions in the meristematic tissue for short time periods ( $<1 \mathrm{~h}$; Figures 4C,D). Simultaneous measurements of internal, meristematic $\mathrm{H}_{2} \mathrm{~S}$ concentrations revealed phytotoxic $\mathrm{H}_{2} \mathrm{~S}$ intrusion into silt/clay-treated plants during night-time in Series 2 from around 23:30 correlating with the recorded period of meristematic tissue anoxia (Figures 4C,D). Internal $\mathrm{H}_{2} \mathrm{~S}$ levels reached a maximum of $8.3 \mu \mathrm{mol} \mathrm{H} \mathrm{S} \mathrm{L} \mathrm{L}^{-1}$ around 08:00 in the morning and then started to decrease shortly after sunrise in response to photosynthetic $\mathrm{O}_{2}$ production leading to disappearance of $\mathrm{H}_{2} \mathrm{~S}$ in the meristem by 10:30. $\mathrm{No} \mathrm{H}_{2} \mathrm{~S}$ intrusion was detected into the control plants.

\section{Effects of Water Column $\mathrm{O}_{2}$ Levels and Silt/Clay on Internal $\mathrm{O}_{2}$ Status}

During night-time, tissue $p \mathrm{O}_{2}$ was derived from $\mathrm{O}_{2}$ in the surrounding water diffusing into the leaves and spreading via aerenchyma to below-ground tissues (Pedersen et al., 1998; Colmer, 2003; Brodersen et al., 2015a). The critical water column $\mathrm{O}_{2}$ level was defined as the water column $p \mathrm{O}_{2}$ below which oxic conditions in the meristematic tissue could no longer be sustained, and this critical $\mathrm{O}_{2}$ level was estimated by plotting the internal $p \mathrm{O}_{2}$ determined in situ against water-column $p \mathrm{O}_{2}$ (Figure 5). In Series 1, the meristematic tissue of the silt/claytreated plant became anoxic at a water-column $\mathrm{pO}_{2}$ of $\sim 5.5 \mathrm{kPa}$ during night-time as compared to $\sim 8.7 \mathrm{kPa}$ in the control plant (Figures 5A,C); a tendency that dramatically changed during prolonged exposure to suspended silt/clay particles (i.e., in Series 2) where the silt/clay-treated plant became anoxic already at a night-time water-column $\mathrm{pO}_{2}$ of $\sim 13 \mathrm{kPa}$ as compared to $\sim 6.4 \mathrm{kPa}$ in the control plant (Figures $5 \mathrm{~B}, \mathrm{D}$ ). These in situ findings aligned well with the lower $\mathrm{O}_{2}$ influx into leaves with silt/clay-cover, as compared to control leaves, determined in the controlled laboratory experiments during darkness (Figures 1-3; Tables 2,3).

The silt/clay-induced shading effects on the intra-plant $p \mathrm{O}_{2}$ during natural light exposure of the seagrass leaf canopy was evaluated by plotting the in situ meristematic $\mathrm{pO}_{2}$ as a function of incident photon irradiance (Figure 6) revealing an $\sim 45 \%$ reduction in meristematic $\mathrm{pO}_{2}$ in plants exposed to suspended silt/clay as compared to control plants, seen as a decrease in $\alpha$, i.e., the slope describing the internal $\mathrm{O}_{2}$ evolution as a function of photon irradiance, from 0.14 to 0.08 (Figure 6). 


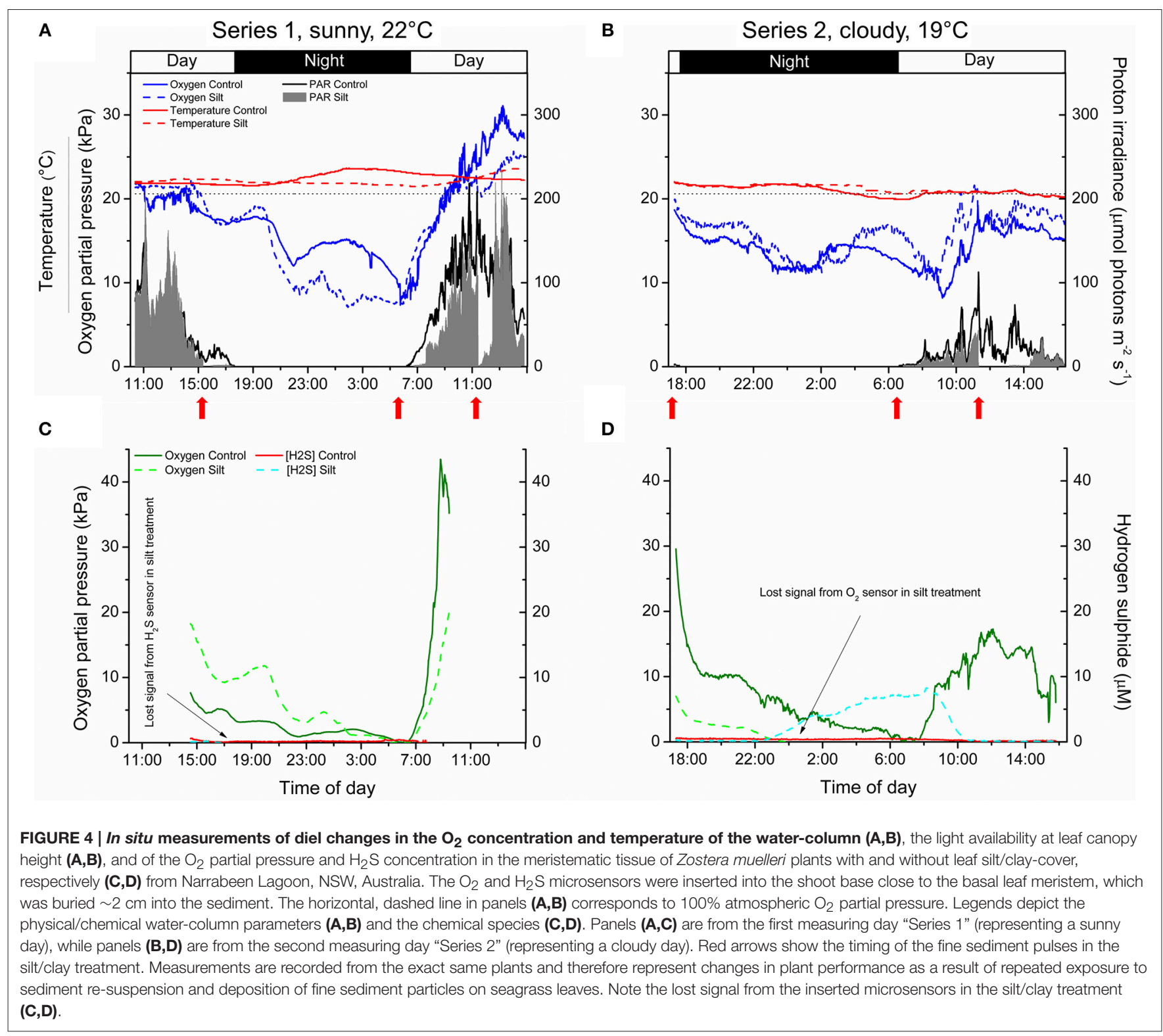

\section{DISCUSSION}

Our results provide strong evidence that silt/clay-cover on seagrass leaves can have substantial negative effects on the plants' photosynthetic activity and efficiency, as well as on the nighttime $\mathrm{O}_{2}$ exchange between leaf tissue and the surrounding water. Reduced internal aeration, and thus decreased belowground tissue oxidation capacity, rendered plants with leaf silt/clay-cover more prone to $\mathrm{H}_{2} \mathrm{~S}$ intrusion even at relatively high water-column $p \mathrm{O}_{2}$ during night-time. Below, we discuss in detail the implications of reduced light availability for photosynthesis owing to silt/clay shading, thicker DBLs, and the introduction of $\mathrm{O}_{2}$ consumption within the DBL itself, on internal aeration and whole plant performance of seagrasses.

\section{Sediment and Silt/Clay Characteristics}

We measured an $\sim 3$.4-fold higher volumetric $\mathrm{O}_{2}$ consumption rate of the fine sediment particles $(<63 \mu \mathrm{m})$, as compared to the bulk sediment, indicative of high microbial activity within the thin silt/clay layer covering the leaf (Table 1). Microbial $\mathrm{O}_{2}$ respiration was the quantitatively most important $\mathrm{O}_{2}$ consuming process of the fine sediment particles, while chemical oxidation only accounted for $\sim 5 \%$ of the total $\mathrm{O}_{2}$ demand (Table 1). Hence, the leaf silt/clay-cover not only impeded gas and nutrient exchange with the surrounding water-column owing to the enhanced thickness of the DBL around the leaves (Figure 2), it also reduced the passive $\mathrm{O}_{2}$ influx across the silt/clay layer during night-time owing to high microbial $\mathrm{O}_{2}$ consumption within the silt/clay layer. 


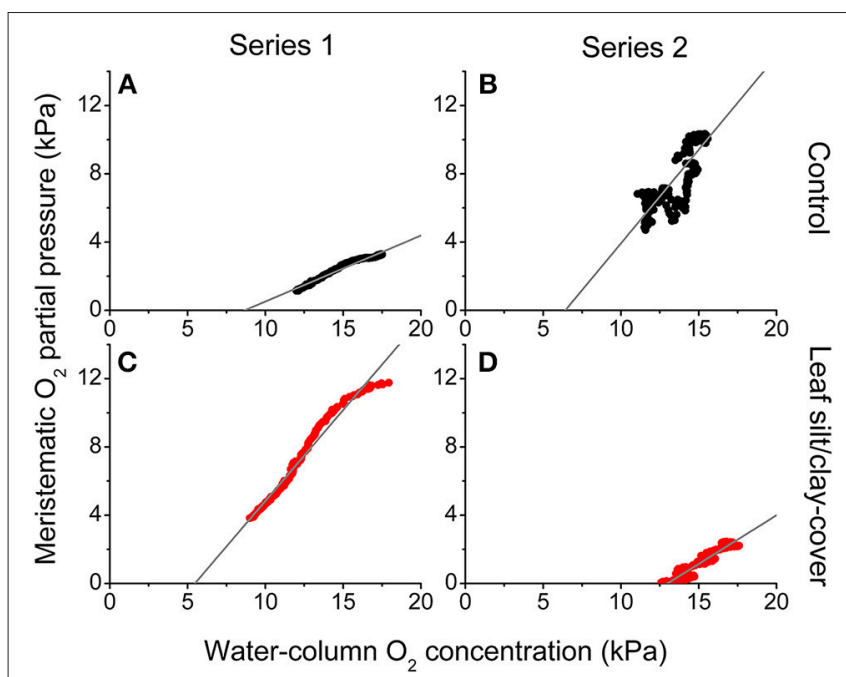

FIGURE 5 | In situ intra-plant $\mathrm{O}_{2}$ status as a function of the $\mathrm{O}_{2}$ partial pressure in the surrounding water-column during night-time. The data were extracted from Figure $\mathbf{4}$ approximately $2 \mathrm{~h}$ after sunset. The gray lines represent a linear regression and are extrapolated to interception with the horizontal $x$-axis, to provide an estimate of the water-column $\mathrm{O}_{2}$ level where the meristematic tissue at the shoot base becomes anoxic $\left(R_{\text {control, Series } 1}^{2}=\right.$ $0.97 ; R_{\text {control, Series 2 }}^{2}=0.70 ; R_{\text {silt/lay-cover, Series 1 }}^{2}=0.97 ; R_{\text {siltclay-cover, Series 2 }}^{2}=0.94$ ). Upper panels (A,B) are measurements from control plants (black symbols), while lower panels (C,D) are measurements from plants with a silt/clay-cover on the leaves (red symbols).

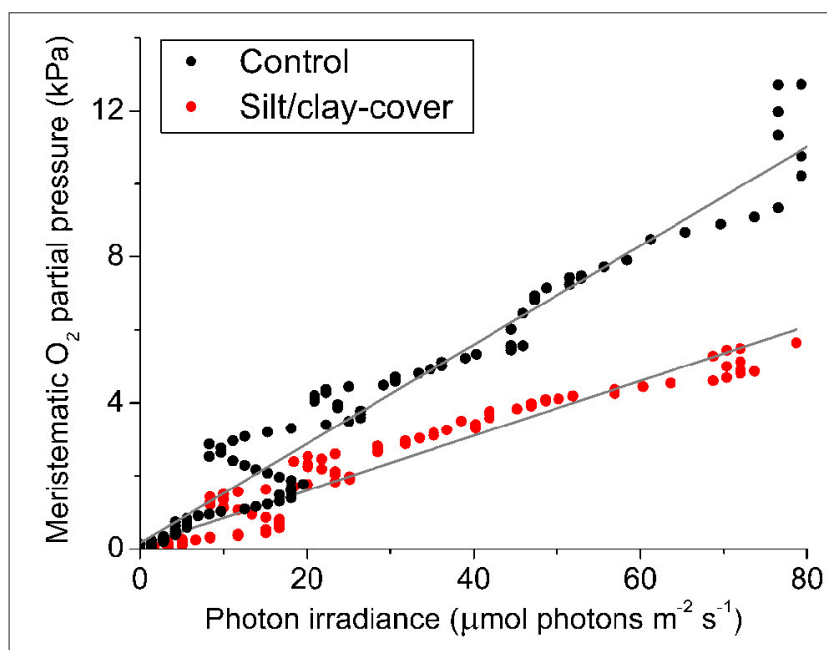

FIGURE 6 | In situ intra-plant $\mathrm{O}_{2}$ status as a function of incident photon irradiance (PAR) during daytime. The data were extracted from Figure 4 at sunrise (Series 1). The intra-plant $\mathrm{O}_{2}$ evolution during the light-limiting phase of PAR were fitted with a linear function (Gray lines) $\left(R_{\text {control }}^{2}\right.$ $\left.=0.95, \alpha_{\text {control }}=0.14 ; R_{\text {silt/lay-cover }}^{2}=0.94, \alpha_{\text {silt/lay-cover }}=0.08\right)$. Black symbols show measurements from control plants, while red symbols show measurements from plants with a silt/clay-cover on the leaves.

\section{Sediment-Cover Effects on Seagrass Photosynthesis and $\mathrm{O}_{2}$ Uptake}

In light, the apparent net photosynthesis rates of Z. muelleri leaves with silt/clay-cover were greatly reduced as compared to control leaves, and the reduction was most pronounced at low to moderate photon irradiances (Figure 3; Table 2). The reduced leaf photosynthesis was, most likely, a combined negative result of lower light availability at the tissue surface and a DBL-impeded uptake of $\mathrm{CO}_{2}$ from the surrounding water-column, potentially leading to enhanced photorespiration and thereby reduced photosynthetic efficiency owing to inorganic carbon limitation (e.g., Maberly, 2014; Figures 1,3; Table 2). Consequently, the compensation irradiance of photosynthesis for plants with leaf silt/clay-cover increased to $\sim 109$ and $145 \mu$ mol photons $\mathrm{m}^{-2}$ $\mathrm{s}^{-1}$, as compared to $\sim 20$ and $53 \mu \mathrm{mol}$ photons $\mathrm{m}^{-2} \mathrm{~s}^{-1}$ for control plants kept in water with $\mathrm{O}_{2}$ at $40 \%$ air equilibrium and $100 \%$ air equilibrium, respectively (Table 3). Silt/clay-cover can thus keep seagrass plants close to their minimum light requirements on days with poor light conditions. However, in the present experimental set-up we were unable to clearly separate the effect of reduced net photosynthesis caused by reduced light (shading by particles) or increased resistance to $\mathrm{CO}_{2}$ influx (thicker DBL) from that of $\mathrm{O}_{2}$ consumption by bacteria within the silt/clay layer.

In darkness, the passive $\mathrm{O}_{2}$ influx was also strongly affected by the leaf silt/clay-cover, causing a reduction of up to $35 \%$ in the $\mathrm{O}_{2}$ supply (Table 2), which resulted in reduced internal aeration (Table 3) especially under hypoxic water-column conditions and thus markedly increased the risk of over-night tissue anoxia. The lower $\mathrm{O}_{2}$ influx was a combined negative result of an increased DBL thickness impeding the exchange of $\mathrm{O}_{2}$ with the surrounding water-column (Figure 2) and high microbial $\mathrm{O}_{2}$ consumption rates within the leaf silt/clay-cover (Figure 2; Table 1). Such reduction in the meristematic $p \mathrm{O}_{2}$ lead to a reduced capability of the silt/clay-covered seagrass plant to aerate its below-ground tissue during night-time increasing the risk for phytotoxic $\mathrm{H}_{2} \mathrm{~S}$ intrusion (Pedersen et al., 2004; Borum et al., 2005; Brodersen et al., 2015b).

Moreover, at high irradiances the silt/clay-induced impeded gas exchange with the water column may also lead to supraoptimal internal $\mathrm{O}_{2}$ levels during daytime, potentially resulting in oxidative stress or damage (Brodersen et al., 2015a). Similarly, elevated temperatures may lead to a $\mathrm{CO}_{2}$ build-up at night-time that could result in a negative feedback on respiration, cellular $\mathrm{pH}$ and rates of dark fixation.

\section{Sediment Re-suspension Effects on Plant Meristematic $\mathrm{O}_{2}$ and $\mathrm{H}_{2} \mathrm{~S}$ Levels}

Diel changes in the meristematic $\mathrm{O}_{2}$ content of seagrasses were mainly driven by irradiance (Figure 4). Experimentally manipulated silt/clay re-suspension within the enclosure of the silt/clay treatment, resulted in a pronounced decrease of light availability for seagrass photosynthesis with up to $3 \mathrm{~h}$ of darkening measured around midday in Series 2 (Figure 4B). The diminished light conditions resulted in reduced photosynthetic $\mathrm{O}_{2}$ evolution and thereby reduced meristematic $\mathrm{pO}_{2}$ in $Z$. muelleri as seen at sunrise in Series 1 (Figure 4C), thus correlating with previous findings by Borum et al. (2005). The photosynthetic efficiency of $Z$. muelleri measured in situ was also strongly affected by the silt/clay exposure, with an almost 
2-fold decrease in the net photosynthetic $\mathrm{O}_{2}$ evolution of plants exposed to fine sediment particles, as compared to control plants at equivalent incident photon irradiances (Figure 6), leading to reduced internal aeration and below-ground tissue oxidation capacity. This was a result of impeded gas exchange with the surrounding water-column due to a thicker DBL in the presence of a sediment cover of leaves leading to lower photosynthetic efficiencies. The in situ measurements thus strongly correlated with findings of a 3-5-fold higher compensation irradiance and an $\sim 2.4$-fold increase in the irradiance at onset of photosynthesis saturation in the laboratory experiments for $Z$. muelleri leaves with silt/clay-cover as compared to control leaves (Figure 3; Table 3).

Critically low meristematic $\mathrm{pO}_{2}$ and/or tissue anoxia were only measured during night-time and occurred for longer periods of time, and at higher water-column $\mathrm{O}_{2}$ levels, for $Z$. muelleri in the silt/clay treatment as compared to the control treatment (Figures 4, 5). This suggests reduced $\mathrm{O}_{2}$ supply from the leaves to the below-ground tissue of $Z$. muelleri plants exposed to fine sediment particles. The reduced meristematic $p \mathrm{O}_{2}$ was caused by (i) the leaf silt/clay-cover induced enhanced DBL thickness impeding the passive $\mathrm{O}_{2}$ influx into the leaves, and (ii) high rates of microbial $\mathrm{O}_{2}$ consumption within the leaf silt/clay layer in line with observations in the laboratory experiments (Figures 1,2). Lowest meristematic $\mathrm{pO}_{2}$ levels were recorded around sunrise, followed by a rapid increase in the meristematic $\mathrm{O}_{2}$ content when sunlight supported leaf photosynthesis (Figures 4C,D). Moreover, our results clearly showed that sediment re-suspension did not have substantial negative effects on the overall $\mathrm{O}_{2}$ conditions within the watercolumn (Figures $\mathbf{4 A , B}$ ) as previously suggested (Erftemeijer and Lewis, 2006), thus underpinning the critical importance of silt/clay leaf covers.

Plants with leaf silt/clay-cover exhibited internal meristematic tissue anoxia at higher water-column $\mathrm{pO}_{2}$ levels $(\sim 45 \%$ of air equilibrium) than plants without leaf silt/clay-cover $(\sim 37 \%$ of air equilibrium), thus correlating with the lower passive $\mathrm{O}_{2}$ influx into leaves with silt/clay-cover during night-time determined in the laboratory experiments (Figures 1,3). The silt/clay-induced negative effect on the intra-plant $\mathrm{O}_{2}$ status was aggravated during prolonged exposure to fine sediment particles in the watercolumn (Figure 5), where the critical water-column $\mathrm{O}_{2}$ level for Z. muelleri increased to $\sim 63 \%$ air saturation after $\sim 54$ h of exposure to experimentally manipulated silt/clay re-suspension (Figure 5). Seagrass plants with leaf silt/clay-cover were thus more vulnerable to low water-column $\mathrm{pO}_{2}$ at night-time and are exposed to an increased risk for $\mathrm{H}_{2} \mathrm{~S}$ intrusion.

Proof of $\mathrm{H}_{2} \mathrm{~S}$ intrusion in seagrasses has only been demonstrated in situ once (Borum et al., 2005) and never under conditions of such high water column $\mathrm{pO}_{2}$ as in the silt/clay-treated plants of this study, which was in strong contrast to the control treatment, where no $\mathrm{H}_{2} \mathrm{~S}$ intrusion was detected (Figures 4C,D). Anoxic conditions in the roots, rhizome and basal leaf meristem of seagrasses lead to ceased radial $\mathrm{O}_{2}$ loss (ROL) from the below-ground tissue into the immediate rhizosphere and thus resulted in sediment-produced $\mathrm{H}_{2} \mathrm{~S}$ reaching the below-ground tissue surface (Brodersen et al., $2015 b$ ). If $\mathrm{H}_{2} \mathrm{~S}$ enters the plant e.g., via, the root apical meristems, the transport of $\mathrm{H}_{2} \mathrm{~S}$ to the basal leaf meristem is relatively fast as it occurs via gas-phase diffusion in the aerenchyma (Pedersen et al., 2004) and this may lead to chemical asphyxiation and thereby enhanced seagrass mortality (Lamers et al., 2013). Normally, $\mathrm{H}_{2} \mathrm{~S}$ intrusion is prevented by plant-derived ROL creating oxic sediment microniches that are sustained as long as the below-ground tissue is supported with sufficient $\mathrm{O}_{2}$ from the leaf canopy (Pedersen et al., 2004; Brodersen et al., 2015b, 2016). Mature regions of seagrass roots do not leak $\mathrm{O}_{2}$, but instead possess barriers to ROL, and thereby most likely to $\mathrm{H}_{2} \mathrm{~S}$ intrusion, composed by Casparian-band like structures in the root endodermis (Barnabas, 1996; Enstone et al., 2003). This important anatomical cell-wall modification significantly reduces the consumption of $\mathrm{O}_{2}$ along the internal diffusion path and thereby ensures an effective $\mathrm{O}_{2}$ transport to the most distal parts of the seagrass plant (Colmer, 2003). At sunrise, photosynthetic $\mathrm{O}_{2}$ evolution in the leaves of the silt/clay-treated plants lead to enhanced internal meristematic $\mathrm{pO}_{2}$ and thereby re-oxidation of intruded $\mathrm{H}_{2} \mathrm{~S}$ around 08:00-10:00 in the morning (Figure 4D), where after the $\mathrm{H}_{2} \mathrm{~S}$ concentration remained below the detection limit.

Unfortunately, such in situ microsensor measurements are extremely challenging to obtain as positioning multiple microsensors simultaneously inside the tissue at the base of the shoot while "SCUBA diving" is very challenging and time consuming, and due to, e.g., sensor breakages during nighttime as a result of fish foraging in the investigated seagrass meadow, as well as, time constrains such as daylight hours when positioning the sensors. Extreme changes in weather conditions did not allow us to perform additional replication. However, our results are very consistent with previous findings in situ and in the laboratory (e.g., Pedersen et al., 2004; Borum et al., 2005, 2006), showing $\mathrm{H}_{2} \mathrm{~S}$ intrusion as soon as the aerenchymal tissue becomes completely anoxic, which only occurred for longer time periods in the silt/clay-treated plant during prolonged exposure to sediment re-suspension (Figures 4, 5). This clearly demonstrates that compromised photosynthesis as a result of prolonged exposure to sediment re-suspension and deposition of fine sediment particles on seagrass leaves can result in inadequate internal tissue aeration and thereby reduced below-ground tissue oxidation capacity, which leaves the plant exposed to intrusion of reduced chemical compounds such as $\mathrm{H}_{2} \mathrm{~S}$. The intra-plant $\mathrm{O}_{2}$ conditions during night-time were similar in both the control plant and silt/clay-exposed plant during Series 1, whereas this changed completely during Series 2, where the same plants showed a very different response and the silt/clay-exposed plant became completely anoxic within a few hours after sunset at high watercolumn $\mathrm{pO}_{2}$ simultaneously with the recording of rapid $\mathrm{H}_{2} \mathrm{~S}$ intrusion (Figures 4, 5).

Settling of fine sediment particles onto seagrass leaves thus severely hampers the plants' performance in both light and darkness, and thereby the health of the seagrass community as a whole. Silt/clay-induced compromised photosynthesis seemed to be the most important impediment to seagrass health in our study. Dredging-induced increased water turbidity therefore represents a severe threat to seagrass communities due to its adverse effects on internal $\mathrm{O}_{2}$ status, and therefore can explain 
the often major seagrass die-off events observed during excessive dredging activities (e.g., York et al., 2015), especially if carried out during summer-time where seagrasses are more prone to tissue anoxia owing to higher respiratory needs (Staehr and Borum, 2011; Raun and Borum, 2013); thus emphasizing the need for minimizing stress-inducing dredging operations for seagrass health.

In conclusion, the present study emphasizes the importance for seagrasses to maintain protective plant-derived oxic microshields within their rhizosphere, as sediment detoxification via $\mathrm{ROL}$ prevents $\mathrm{H}_{2} \mathrm{~S}$ from accumulating to very high toxic levels in the sediment and thus prevents $\mathrm{H}_{2} \mathrm{~S}$ from reaching the tissue surface at the most vulnerable regions of the plants (Carlson et al., 1994; Brodersen et al., 2015b). Silt/clay-induced $\mathrm{H}_{2} \mathrm{~S}$ intrusion into $Z$. muelleri seemed tightly coupled to prolonged exposure to sediment re-suspension, such as typically found during harbor dredging activities (York et al., 2015) and resulting from river plumes (Petus et al., 2014). Leaf silt/clay-covers thus impeded the plants' performance and thereby their resilience toward $\mathrm{H}_{2} \mathrm{~S}$ intrusion. This was as a result of a combined negative plant response to the reduced light availability for photosynthesis, thicker DBLs around leaves and enhanced leaf surface microbial respiration rates, all leading to inadequate internal aeration and reduced below-ground tissue oxidation capacity (Figure 4). Turbidity-generating activities such as dredging operations in close proximity to seagrass meadows can have strong negative effects on the fitness level and health of seagrasses through multiple pathways and may lead to increased seagrass mortality.

\section{REFERENCES}

Barnabas, A. D. (1996). Casparian band-like structures in the root hypodermis of some aquatic angiosperms. Aquat. Bot. 55, 217-225. doi: 10.1016/S0304-3770(96)01072-8

Binzer, T., Borum, J., and Pedersen, O. (2005). Flow velocity affects internal oxygen conditions in the seagrass Cymodocea nodosa. Aquat. Bot. 83, 239-247. doi: 10.1016/j.aquabot.2005.07.001

Borum, J., Pedersen, O., Greve, T. M., Frankovich, T. A., Zieman, J. C., Fourqurean, J. W., et al. (2005). The potential role of plant oxygen and sulphide dynamics in die-off events of the tropical seagrass, Thalassia testudinum. J. Ecol. 93, 148-158. doi: 10.1111/j.1365-2745.2004.00943.x

Borum, J., Sand-Jensen, K., Binzer, T., Pedersen, O., and Greve, T. M. (2006). "Oxygen movement in seagrasses," in Seagrasses: Biology, Ecology and Conservation, eds A. W. D. Larkum, J. R. Orth, and C. M. Duarte (Dordrecht Berlin: Springer), 255-270.

Brodersen, K. E., Koren, K., Lichtenberg, M., and Kühl, M. (2016). Nanoparticle-based measurements of $\mathrm{pH}$ and $\mathrm{O}_{2}$ dynamics in the rhizosphere of Zostera marina L.: effects of temperature elevation and light-dark transitions. Plant Cell Environ. 39, 1619-1630. doi: 10.1111/pce. 12740

Brodersen, K. E., Lichtenberg, M., Paz, L.-C., and Kühl, M. (2015a). Epiphytecover on seagrass (Zostera marina L.) leaves impedes plant performance and radial $\mathrm{O}_{2}$ loss from the below-ground tissue. Front. Mar. Sci. 2:58. doi: 10.3389/fmars.2015.00058

Brodersen, K. E., Nielsen, D. A., Ralph, P. J., and Kühl, M. (2014). A split flow chamber with artificial sediment to examine the below-ground microenvironment of aquatic macrophytes. Mar. Biol. 161, 2921-2930. doi: 10.1007/s00227-014-2542-3

Brodersen, K. E., Nielsen, D. A., Ralph, P. J., and Kühl, M. (2015b). Oxic microshield and local $\mathrm{pH}$ enhancement protects Zostera muelleri from

\section{AUTHOR CONTRIBUTIONS}

$\mathrm{KB}, \mathrm{OP}, \mathrm{MK}, \mathrm{PR}$, and MR designed the research. $\mathrm{KB}, \mathrm{OP}, \mathrm{KH}$, $\mathrm{VS}$, and AF conducted the experiments. $\mathrm{KB}$ processed the data with help from OP and $\mathrm{KH}$. KB, OP, MK analyzed the data. $\mathrm{KB}$ wrote the manuscript with editorial help from OP, MK, PR, and MR. All authors have given approval to the final version of the manuscript.

\section{ACKNOWLEDGMENTS}

We thank all volunteers from University of Technology Sydney (UTS) who kindly helped with setting up the platform in Narrabeen Lagoon and supervised all our equipment during night-time. We acknowledge the workshop at UTS for constructing the platform and enclosures. The research was funded by grants from the Australian Research Council (ARC; LP 110200454) (PR, MR, and MK), the Augustinus Foundation $(\mathrm{KB}$ and $\mathrm{KH})$, P. A. Fiskers Fund $(\mathrm{KB})$, Jorck and Wife's Fund $(\mathrm{KB})$, the Oticon Foundation $(\mathrm{KH})$, and the Danish Council for Independent Research | Natural Sciences (MK and OP). The research was conducted under the scientific collection and field-work permit (P12/0020-1.2).

\section{SUPPLEMENTARY MATERIAL}

The Supplementary Material for this article can be found online at: http://journal.frontiersin.org/article/10.3389/fpls.2017. 00657/full\#supplementary-material

sediment derived hydrogen sulphide. New Phytologist 205, 1264-1276. doi: 10.1111/nph.13124

Carlson, J., Paul, R., Yarbro, L. A., and Barber, T. R. (1994). Relationship of sediment sulfide to mortality of Thalassia testudinum in Florida Bay. Bull. Mar. Sci. 54, 733-746.

Chartrand, K. M., Bryant, C. V., Carter, A. B., Ralph, P. J., and Rasheed, M. A. (2016). Light thresholds to prevent dredging impacts on the Great Barrier Reef seagrass, Zostera muelleri ssp. capricorni. Front. Mar. Sci. 3:106. doi: 10.3389/fmars.2016.00106

Colmer, T. D. (2003). Long-distance transport of gases in plants: a perspective on internal aeration and radial oxygen loss from roots. Plant Cell Environ. 26, 17-36. doi: 10.1046/j.1365-3040.2003.00846.x

Cutroneo, L., Castellano, M., Ferranti, M. P., Povero, P., Tucci, S., and Capello, M. (2013). Use of optical and acoustic instruments to study the turbid plumes generated by three different types of dredges during dredging activities inside and outside of a port. J. Soils Sediments 13, 1645-1654. doi: 10.1007/s11368-013-0756-5

Dennison, W. C. (1987). Effects of light on seagrass photosynthesis, growth and depth distribution. Aquat. Bot. 27, 15-26. doi: 10.1016/0304-3770(87)90083-0

Duarte, C. M. (1991). Seagrass depth limits. Aquat. Bot. 40, 363-377. doi: 10.1016/0304-3770(91)90081-F

Enstone, D. E., Peterson, C. A., and Ma, F. (2003). Root endodermis and exodermis: structure, function, and responses to the environment. J. Plant Growth Regul. 21, 335-351. doi: 10.1007/s00344-003-0002-2

Erftemeijer, P. L. A., and Lewis, R. R. III. (2006). Environmental impacts of dredging on seagrasses: a review. Mar. Pollut. Bull. 52, 1553-1572. doi: 10.1016/j.marpolbul.2006.09.006

Fourqurean, J. W., and Zieman, J. C. (1991). Photosynthesis, respiration and whole plant carbon budget of the seagrass Thalassia testudinum. Mar. Ecol. Prog. Ser. 69, 161-170. doi: 10.3354/meps 069161 
Frederiksen, M. S., and Glud, R. N. (2006). Oxygen dynamics in the rhizosphere of Zostera marina: a two-dimensional planar optode study. Limnol. Oceanogr. 51, 1072-1083. doi: 10.4319/lo.2006.51.2.1072

Gambi, M., Nowell, A., and Jumars, P. (1990). Flume observations on flow dynamics in Zostera marina (eelgrass) beds. Mar. Ecol. Prog. Ser. 61, 159-169. doi: 10.3354/meps061159

González-Ortiz, V., Egea, L. G., Jiménez-Ramos, R., Moreno-Marín, F., Pérez-Lloréns, J. L., Bouma, T. J., et al. (2014). Interactions between seagrass complexity, hydrodynamic flow and biomixing alter food availability for associated filter-feeding organisms. PLOS ONE 9:e104949. doi: 10.1371/journal.pone.0104949

Greve, T. M., Borum, J., and Pedersen, O. (2003). Meristematic oxygen variability in eelgrass (Zostera marina). Limnol. Oceanogr. 48, 210-216. doi: $10.4319 /$ lo.2003.48.1.0210

Hamisi, M., Díez, B., Lyimo, T., Ininbergs, K., and Bergman, B. (2013). Epiphytic cyanobacteria of the seagrass Cymodocea rotundata: diversity, diel nifH expression and nitrogenase activity. Environ. Microbiol. Rep. 5, 367-376. doi: $10.1111 / 1758-2229.12031$

Hasler-Sheetal, H., and Holmer, M. (2015). Sulfide Intrusion and Detoxification in the Seagrass Zostera marina. PLoS ONE 10:e0129136. doi: 10.1371/journal.pone.0129136

Holmer, M., and Bondgaard, E. J. (2001). Photosynthetic and growth response of eelgrass to low oxygen and high sulfide concentrations during hypoxic events. Aquat. Bot. 70, 29-38. doi: 10.1016/S0304-3770(00)00142-X

Holmer, M., and Hasler-Sheetal, H. (2014). Sulfide intrusion in seagrasses assessed by stable sulfur isotopes-a synthesis of current results. Front. Mar. Sci. 1:64. doi: 10.3389/fmars.2014.00064

Hurd, C. L. (2000). Water motion, marine macroalgal physiology, and production. J. Phycol. 36, 453-472. doi: 10.1046/j.1529-8817.2000.99139.x

Jensen, S. I., Kühl, M., Glud, R. N., Jørgensen, L. B., and Prieme, A. (2005). Oxic microzones and radial oxygen loss from roots of Zostera marina. Mar. Ecol. Prog. Ser. 293, 49-58. doi: 10.3354/meps293049

Jeroschewski, P., Steuckart, C., and Kühl, M. (1996). An amperometric microsensor for the determination of $\mathrm{H}_{2} \mathrm{~S}$ in aquatic environments. Anal. Chem. 68, 4351-4357. doi: 10.1021/ac960091b

Jørgensen, B. B., and Des Marias, D. J. (1990). The diffusive boundary layer of sediments: oxygen microgradients over a microbial mat. Limnol. Oceanogr. 35, 1343-1355. doi: 10.4319/lo.1990.35.6.1343

Jørgensen, B. B., and Revsbech, N. P. (1985). Diffusive boundary layers and the oxygen uptake of sediments and detritus. Limnol. Oceanogr. 30, 111-122. doi: 10.4319/lo.1985.30.1.0111

Koch, E. W. (1994). Hydrodynamics, diffusion-boundary layers and photosynthesis of the seagrasses Thalassia testudinum and Cymodocea nodosa. Mar. Biol. 118, 767-776. doi: 10.1007/BF00347527

Koren, K., Brodersen, K. E., Jakobsen, S. L., and Kühl, M. (2015). Optical sensor nanoparticles in artificial sediments - a new tool to visualize $\mathrm{O}_{2}$ dynamics around the rhizome and roots of seagrasses. Environ. Sci. Technol. 49, 2286-2292. doi: 10.1021/es505734b

Kühl, M., and Revsbech, N. P. (2001). "Biogeochemical microsensors for boundary layer studies," in The Benthic Boundary Layer, eds B. P. Boudreau and B. B. Jørgensen (New York, NY: Oxford University Press), 180-210.

Kühl, M., Steuckart, C., Eickert, G., and Jeroschewski, P. (1998). A $\mathrm{H}_{2} \mathrm{~S}$ microsensor for profiling sediments and biofilms: application in acidic sediment. Aquat. Microb. Ecol. 15, 201-209. doi: 10.3354/ame015201

Lamers, L. P., Govers, L. L., Janssen, I. C., Geurts, J. J., Van der Welle, M. E., Van Katwijk, M. M., et al. (2013). Sulfide as a soil phytotoxin-a review. Front. Plant Sci. 4:268. doi: 10.3389/fpls.2013.00268

Larkum, A. W. D., Koch, E. M., and Kühl, M. (2003). Diffusive boundary layers and photosynthesis of the epilithic algal community of coral reefs. Mar. Biol. 142, 1073-1082. doi: 10.1007/s00227-003-1022-y

Maberly, S. C. (2014). The fitness of the environments of air and water for photosynthesis, growth, reproduction and dispersal of photoautotrophs: an evolutionary and biogeochemical perspective. Aquat. Bot. 118, 4-13. doi: 10.1016/j.aquabot.2014.06.014

Pedersen, O., Binzer, T., and Borum, J. (2004). Sulphide intrusion in eelgrass (Zostera marina L.). Plant Cell Environ. 27, 595-602. doi: $10.1111 / j .1365-3040.2004 .01173 . x$
Pedersen, O., Borum, J., Duarte, C. M., and Fortes, M. D. (1998). Oxygen dynamics in the rhizosphere of Cymodocea rotundata. Mar. Ecol. Prog. Ser. 169, 283-288. doi: 10.3354/meps169283

Pedersen, O., Colmer, T. D., Borum, J., Zavala-Perez, A., and Kendrick, G. A. (2016). Heat stress of two tropical seagrass species during low tides - impact on underwater net photosynthesis, dark respiration and diel in situ internal aeration. New Phytol. 210, 1207-1218. doi: 10.1111/nph.13900

Pedersen, O., Colmer, T. D., and Sand-Jensen, K. (2013). Underwater photosynthesis of submerged plants - recent advances and methods. Front. Plant Sci. 4:140. doi: 10.3389/fpls.2013.00140

Pedersen, O., Pulido, C., Rich, S. M., and Colmer, T. D. (2011). In situ $\mathrm{O}_{2}$ dynamics in submerged Isoetes australis: varied leaf gas permeability influences underwater photosynthesis and internal $\mathrm{O}_{2}$. J. Exp. Bot. 62, 4691-4700. doi: $10.1093 / \mathrm{jxb} / \mathrm{err} 193$

Pereira, S., Zille, A., Micheletti, E., Moradas-Ferreira, P., De Philippis, R., and Tamagnini, P. (2009). Complexity of cyanobacterial exopolysaccharides: composition, structures, inducing factors and putative genes involved in their biosynthesis and assembly. FEMS Microbiol. Rev. 33, 917-941. doi: 10.1111/j.1574-6976.2009.00183.x

Pérez-Pérez, M. E., Lemaire, S. D., and Crespo, J. L. (2012). Reactive oxygen species and autophagy in plants and algae. Plant Physiology 160, 156-164. doi: 10.1104/pp.112.199992

Petus, C., Collier, C., Devlin, M., Rasheed, M., and McKenna, S. (2014). Using MODIS data for understanding changes in seagrass meadow health: a case study in the Great Barrier Reef (Australia). Mar. Environ. Res. 98, 68-85. doi: 10.1016/j.marenvres.2014.03.006

Ralph, P. J., Durako, M. J., Enríquez, S., Collier, C. J., and Doblin, M. A. (2007). Impact of light limitation on seagrasses. J. Exp. Mar. Biol. Ecol. 350, 176-193. doi: 10.1016/j.jembe.2007.06.017

Raun, A. L., and Borum, J. (2013). Combined impact of water column oxygen and temperature on internal oxygen status and growth of Zostera marina seedlings and adult shoots. J. Exp. Mar. Biol. Ecol. 441, 16-22. doi: 10.1016/j.jembe.2013.01.014

Raun, A. L., Borum, J., and Sand-Jensen, K. (2010). Influence of sediment organic enrichment and water alkalinity on growth of aquatic isoetid and elodeid plants. Freshw. Biol. 55, 1891-1904. doi: 10.1111/j.1365-2427.2010.02423.x

Raven, J. A., and Scrimgeour, C. M. (1997). The influence of anoxia on plants of saline habitates with special reference to the sulfur cycle. Ann. Bot. 79, 79-86. doi: 10.1093/oxfordjournals.aob.a010309

Revsbech, N. P. (1989). An oxygen microsensor with a guard cathode. Limnol. Oceanogr. 34, 474-478. doi: 10.4319/lo.1989.34.2.0474

Spilling, K., Titelman, J., Greve, T. M., and Kühl, M. (2010). Microsensor measurements of the external and internal microenvironment of Fucus vesiculosus (Phaeophyceae). J. Phycol. 46, 1350-1355. doi: $10.1111 / j .1529-8817.2010 .00894 . x$

Staehr, P. A., and Borum, J. (2011). Seasonal acclimation in metabolism reduces light requirements of eelgrass (Zostera marina). J. Exp. Mar. Biol. Ecol. 407, 139-146. doi: 10.1016/j.jembe.2011.05.031

Webb, W. L., Newton, M., and Starr, D. (1974). Carbon-dioxide exchange of Alnus-rubra - mathematical-model. Oecologia 17, 281-291. doi: 10.1007/BF003 45747

York, P. H., Carter, A. B., Chartrand, K., Sankey, T., Wells, L., and Rasheed, M. A. (2015). Dynamics of a deep-water seagrass population on the Great Barrier Reef: annual occurrence and response to a major dredging program. Sci. Rep. 5:13167. doi: 10.1038/srep13167

Conflict of Interest Statement: The authors declare that the research was conducted in the absence of any commercial or financial relationships that could be construed as a potential conflict of interest.

Copyright (๑) 2017 Brodersen, Hammer, Schrameyer, Floytrup, Rasheed, Ralph, Kühl and Pedersen. This is an open-access article distributed under the terms of the Creative Commons Attribution License (CC BY). The use, distribution or reproduction in other forums is permitted, provided the original author(s) or licensor are credited and that the original publication in this journal is cited, in accordance with accepted academic practice. No use, distribution or reproduction is permitted which does not comply with these terms. 